\title{
PERENCANAAN PELAKSANAAN PEMBELAJARAN TATAP MUKA DI MASA PANDEMI PADA SMK KRISTEN TAGARI
}

\author{
${ }^{1}$ Emik Pattanang, ${ }^{2}$ Mesta Limbong, ${ }^{3}$ Witarsa Tambunan
}

1,2,3 Magister Administrasi Pendidikan PPs-UKI, Jakarta, Indonesia

e-mail: witarsa.oke@gmail.com

mesta.limbong@uki.ac.id

\begin{tabular}{l|l|l} 
Received : Mei, 2021 & Accepted : Juni, 2021 & Published: Juli, 2021
\end{tabular}

\begin{abstract}
This study discusses the planning carried out by schools for the implementation of face-to-face learning during the pandemic in accordance with the government's decision to reopen face-to-face learning in July 2021. The purpose of this research is to find alternative solutions that can be done by schools in making plans. faceto-face learning that is safe from the transmission of covid-19. In the plan, several things can be done by schools, among others: 1). Vaccination of all educators and education personnel in schools, 2). Increasing the immunity of students, educators and education staff, 3). Preparing facilities and infrastructure in accordance with the health protocol. In this study using a qualitative method with a cause-andeffect approach that is described in the form of a problem tree, then expectations are described in the form of a target tree and alternative solutions that can be done to realize the expectations that have been determined previously in crash in the form of an alternative tree. This research was carried out at the Tagrai Rantepao Christian Vocational School.
\end{abstract}

Keywords :planning, face-to-face learning, pandemic period

\begin{abstract}
Abstrak
Penelitian ini membahas tentang perencanaan yang di lakukan oleh sekolah untuk pelaksanaan pembelajaran tatap muka di masa pandemic sesuai dengan keputusan pemerintah yang akan membuka kembali pembelajaran tatap muka pada Juli 2021 mendatang .Adapun tujuan penelitian ini yaitu mencari solusi alternative yang dapat dilakukan oleh sekolah dalam membuat perencenaan pembelajaran tatap muka yang yang aman dari penularan covid-19. Di dalam perencanaan tersebut beberapa hal yang dapat di lakukan sekolah anatara lain: 1).Melakukan vaksinasi kepada seluruh pendidik dan tenaga kependidikan yang ada di sekolah ,2).Meningkatkan imun peserta didik,pendidik dan tenaga kependidikan, 3).Mempersiapkan sarana dan prasarana yang sesuai protocol kesehatan .Pada penelitian ini menggunakan metode kualititaif dengan pendekatan sebab-akibat yang di jabarkan dalam bentuk pohon masalah,kemudian harapan-harapan di jabarkan dalam bentuk pohon sasaran dan alternative solusi yang dapat di lakukan untuk mewujudkan harapan yang telah di tentukan sebelumnya di jabrakan dalam bentuk pohon alternative.Adappun penelitian ini di lakukan di SMK Kristen Tagrai Rantepao.
\end{abstract}

Kata Kunci: perencanaan, pembelajaran tatap muka, masa pandemi 
Citation: Pattanang, E., Limbong, M., \& Tambunan, W. (2021). PERENCANAAN PELAKSANAAN PEMBELAJARAN TATAP MUKA DI MASA PANDEMI PADA SMK KRISTEN TAGARI .Jurnal Manajemen Pendidikan, 10(2), 112-120. Retrieved from http://ejournal.uki.ac.id/index.php/imp/article/view/3275

\section{PENDAHULUAN}

Kebijakan Pemerintah tentang pembelajaran tatap muka terbatas untuk seluruh satuan pendidikan atau sekolah yang akan mulai di laksanakan kembali pada Juli 2021 mendatang. Hal ini berdasarkan surat keputusan bersama empat mentri yaitu mentri pendidikan dan kebudayaan,mentri kesahatan, mentri agama dan mentri dalam negri tentang panduan penyelenggraaan pembelajaran di masa pandemic coronavirus Disease 2019(covid19).(Kompas.com). Ada dua alasan mengapa kebijkan pembelajaran tatap muka di berlakukan menurut mentri pendidikan dan Kebudayaan Nadiem Anwar Makrim yang pertama adalah para pendidik dan tenaga kependidikan telah di vaksinasi dan yang kedua adalah mencegah lost of learning karena pendidikan di Indonesia sudah tertinggal dari negara lain selama pandemi.

Sebagaimana di ketahui sebelumnya kurang lebih 1 tahun pemerintah pemberlakukan Pembelajaran Jarak Jauh (PJJ) Di mana proses interkasi antara pendidik dan peserta didik terjadi di tempat dan dimungkinkan di waktu yang berbeda .Hal ini di lakukan untuk mencegah penularan Covid-19. Namun Pembelajaran Jarak Jauh yang di lakukan selama ini berdampak pada kualtitas pendidikan yang semakin menurun. Kebijakan pemerintah untuk membuka kembali sekolah dengan melakukan pembelajaran tatap muka membuat pihak sekolah harus mulai melakukan perencanaan yang efektif dan efesien tentang pelaksanaan pembelajaran tatap muka.di tengah pandemi yang masih terus terjadi. Oleh karena itu, agar program pemerintah untuk membuka kembali pembelajaran tatap muka dapat terlaksana dengan baik dan terhindar dari penularan Covid-19.Penulis menganggap sangat penting untuk melakukan perencanaan yang baik sebelum melaksanakan pembelajaran tatap muka .Mulai dari persiapan sarana dan prasarana yang harus sesuai dengan protocol kesehatan,vaksinasi kepada guru dan pegawai di yang ada di sekolah hingga mendapatkan ijin orangtua siswa untuk mengijinkan anka mereka untuk mengikuti pembelajaran tatap muka. Penelitian ini bertujuan untuk memberikan solusi alternative yang dapat dilakukan oleh sekolah dalam membuat perencanaan pembelajaran tatap muka agar pembelajaran tatap muka aman dari penularan covid-19.

\section{Pengertian Perencanaan}

Ketika sebuah kegiatan akan di lakukan pada masa yang akan datang .Agar kegiatan tersebut dapat berjalan sesuai dengan yang di harapkan,haruslah di lakukan perencanaan terlebih dahulu.Beberapa ahli menjelaskan tentang pengertian dari Perencanaan .Menurut Garth N.Jone perencanaan adalah segala proses pemilihan dan pengembangan dari pada tindakan yang paling baik untuk pencapaian tugas. Perencanaan jug dapat di artikan sebuah proses pemikiran dalam menetukan hal yang akan di kerjakan untuk masa yang akan datang dalam rangka mencapai suatu hasil.(Siagian,Terry,Kusmiadi).dari beberapa pengertian perencanaan maka dapat di simpulkan Perencanaan adalah suatu proses yang dilakukan untuk menentukan hal-hal terbaik yang dapat di lakukan untuk masa mendatang agar tujuan yang telah di tentukan dapat tercapai.

Menurut George R Terry ada beberapa ciri perencanaan yang baik.Perencanaan yang baik dapat dinilai jika adanya :1)Perencanaan disusun sesuai dengan tujuan perusahaan.2). Tepat sasaran. 3). Pimpinan menjalankan fungsinya sebagai seorang coordinator. 4). Anggota atau karyawan berada dalam satu koordinasi. 5). . Anggota atau karyawan menjalankan fungsinya sesuai dengan perencanaan program. 6). Adanya peningkatan kualitas kerja karyawan atau anggota. 7). Perencanaan berhasil membuat sebuah pelaksanaa. 8). Adanya pembagian sub-sub koordinasi untuk menjalankan sebuah program. 9). Adanya kesepahaman antara pimpinan dengan karyawan 
atau anggotanya dalam membuat sebuah perencanaan. Pada umumnya perencanaan dilakukan di awal baik dilakukan secara individu maupun kelompok sebelum sebuah kegiatan di dilaksanakan.Perencanaan yang matang dapat meminimalisir kesalahan yang dapat terjadi ketika sebuah kegiatan berlangsung.

\section{Pengertian Pembelajaran Tatap Muka}

Sebelum menjelaskan apa yang di maksud dengan pembelajaran tatap muka, perlu di ketahui terlebih dahulu apa yang di maksud dengan Pembelajaran tatap muka..Menurut Dimyati dan Mudjiono (dalam Sagala, 2009), pembelajaran adalah kegiatan pendidik atau guru secara terprogram dalam desain instruksional untuk membuat peserta didik belajar secara aktif yang menekankan pada penyediaan bahan ajar dan sumber belajar. Sementara pengertian pembelajaran sesuai UUSPN No. 20 tahun 2003 menyatakan pembelajaran adalah proses interaksi peserta didik dengan pendidik dan sumber belajar pada suatu lingkungan belajar. Dengan demikian dapat di simplukan Pembelajaran tatap muka adalah adalah kegiatan proses interaksi antara peserta didik dengan pendidik dengan sumber belajar yang terjadi secara langsung pada waktu yang sama dan tempat yang sama. Karakteristik pembelajaran tatap muka adalah kegiatan yang terencana berorientasi pada tempat, serta interaksi sosial dalam ruang kelas.(Rizky Amelia,2019)

Meski pembelajaran tatap muka akan di berlakukan, namun pembelajaran tatap muka di masa pandemic pelakasanaan nya tidak lah sama persis dengan pembelajaran pada masa normal sehingga di butuhkan pemilihan startegi yang tepat agar pelaksanaan pembelajaran tatap muka berjalan dengan maksimal. Ada dua Startegi yang dapat di lakukan seperti pendekatan pembelajaran yang berpusat pada guru yang di sebut ekspositori maupun pendekatan pembelajaran yang berpusat pada siswa yang di sebut diskoveri inkuiri.( Ying, Y. (2007). Pemilihan strategi ekspositori dilakukan atas pertimbangan,Karakteristik peserta didik dengan kemandirian belum memadai,Sumber referensi terbatas,Jumlah pesera didik dalam kelas banyak, Alokasi waktu terbatas dan Jumlah materi (tuntutan kompetensi dalam aspek pengetahuan) atau bahan banyak. Pemelihan strategi di skoveri inkuiri di lakukan atas pertimbangan yaitu : Karakteristik peserta didik dengan kemandirian cukup memadai,Sumber referensi, alat, media, dan bahan cukup,Jumlah peserta didik dalam kelas tidak terlalu banyak,Materi pembelajaran tidak terlalu luas dan Alokasi waktu cukup tersedia. Sementara itu, menurut Mentri Pendidikan Dan Kebudayaan Dadiem Anwar Makarim Pembelajaran tatap muka merupakan model pembelajaran terbaik yang tidak bisa digantikan. Hal tersebut di sampikan pada jumpa pers Senin (13/7) secara virtual .menurutnya Ke depan pembelajaran tatap muka akan semakin diperkuat dengan kombinasi pemanfaatan teknologi yang sudah diterapkan secara masif di masa pandemi Covid-19 ini.

\section{Pengertian Pandemi Covid-19}

Pandemi adalah sebuah epidemi yang telah menyebar ke berbagai benua dan negara, dan umumnya menyerang banyak orang. Sementara epidemi sendiri merupakan sebuah istilah yang telah digunakan untuk mengetahui peningkatan jumlah kasus penyakit secara tiba-tiba pada suatu populasi area tertentu.Pasalnya, istilah pandemi tidak digunakan untuk menunjukkan tingginya tingkat suatu penyakit, melainkan hanya memperlihatkan tingkat penyebarannya saja. Covid-19 adalah Penyakit coronavirus 2019.Virus yang pertaama kali di identifkasi pada Desember 2019 di Wuhan Cina di sebabkan oleh akut sindrom pernafasan coronavirus 2 (SARS-CoV-2) kemudian lebih kenal dengan sebutan COVID-19. Virus ini memiliki gejala yang berbeda pada setiap orang,namun pada umumnya orang yang terjangkit covid-19 mengalami gelaja, seperti susah bernapas, demam, kepala pusing, hilang indra penciuman dan hilangnya indra perasa..Meski pertama kali di temukan di Wuhan namun Covid-19 menyebar begitu cepat ke seluruh dunia. Hal ini disebabkan karena system penularan covid-19 dapat melalui udara, Virus ini ditularkan terutama melalui jalur pernapasan, ketika orang menghirup tetesan dan partikel yang dilepaskan orang yang terinfeksi saat mereka bernapas, berbicara, batuk, bersin atau bernyanyi.

Sebelum di tetapkan sebagai pandemi WHO (Worth Health Organization) pada tanggal 30 Januari 2020 menetapkan Covid-19 sebagai kesehatan darurat masyarakat peduli internasional. Pada tanggal 11 Maret 2020 WHO (Worth Health Organization) menetapkan Covid-19 sebagai 
pandemi.Bahkan WHO menjadikan Covid-19 sebagai sala satu pandemic paling mematikan dalam sejarah.Ini di dasarkan banyaknya corban jiwa akibat covid-19 hingga Mei 2021 lebih 186 juta kasus telah di konfirmasi dan telah menelan korban jiwa 3,5 juta.(Wikipedia.org).

\section{METODE PENELITIAN}

Penelitian ini di lakukan di sala satu Sekolah Menengah Kejuruan (SMK) swasta di kabupaten Toraja Utara, Sulawesi Selatan yakni SMK Kristen Tagari. Pada penelitian ini menggunakan metode kualititaif dengan pendekatan sebab-akibat. Pengumpulan data dengan cara wawancara kepada pihak yang berwenang di SMK Kristen Tagari.Antara lain Kepala Sekola, Wakil Kepala Sekolah bagian Sarana dan Prasarana. Selain metode wawancara pengumpulan data juga dilakukan dengan cara survei keadaan sekolah yang di alami langsung oleh penulis. Hasil pengumpulan data kemudian di analisis yang di jabarkan dalam bentuk pohon masalah,kemudian harapan-harapan di jabarkan dalam bentuk pohon sasaran dan alternative solusi yang dapat di lakukan untuk mewujudkan harapan yang telah di tentukan sebelumnya di pohon sasaran di jabarkan dalam bentuk pohon alternative.

\section{HASIL DAN PEMBAHASAN}

Pohon Masalah

Adapun langkah-langkah dalam pembuatan pohon masalah yaitu: Mengidentifikasi masalah. Dari identifkasi masalah yang di lakukan ditemukan pokok masalah adalah Perencanaan Pelaksanaan pembelajaran tatap muka belum optimal. Setelah menemukan pokok masalah selanjutnya memindahkan pokok masalah yang ada kedalam kedalam kotak masalah utama.Lihat pada gambar 1.

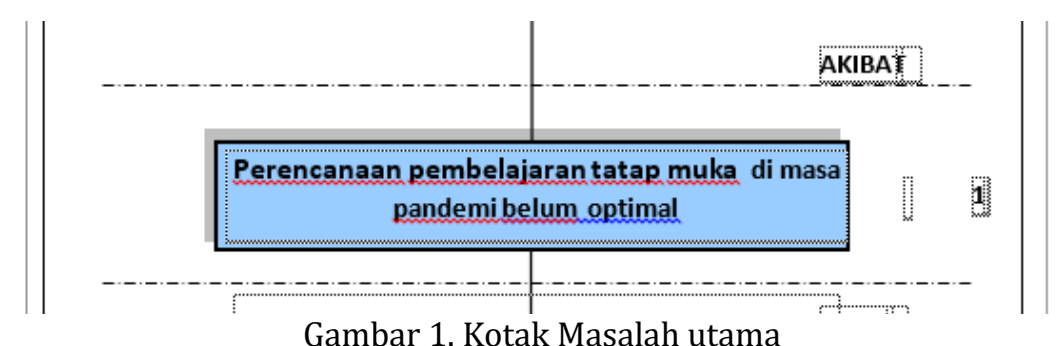

Langkah selanjutnya adalah mengidentifikasi apa yang menyebabkan pokok masalah tersebut terjadi. Setelah mengetahui penyebabnya, selanjutnya sebab-sebab tersebut di pindahkan kedalam kotak sebab di bawah kotak masalah. Seperti pada gambar 2

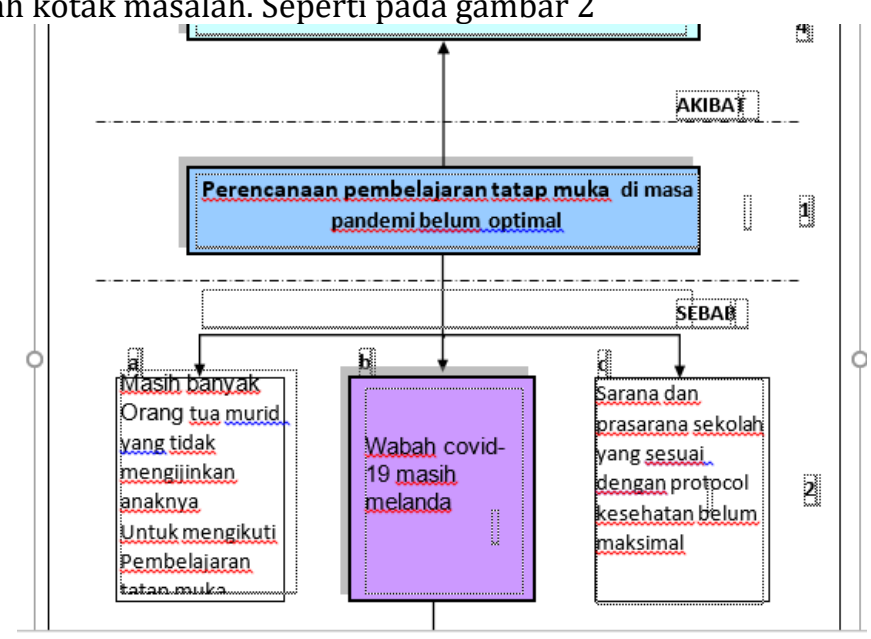

Gambar 2.Kotak Sebab Masalah 
Langkah selanjutnya adalah memilih salah satu penyebab pokok masalah yang akan di di kembangkan untuk menemukan solusinya ,Kemudian mengulangi mengidentifikasi penyebab dari penyebab masalah utama yang telah di tentukan sebelumnya,sebab-sebab tersebut kemudian di pindahkan dalam kotak sebab di bawah kotak sebab utama.Lihat Gambar 3

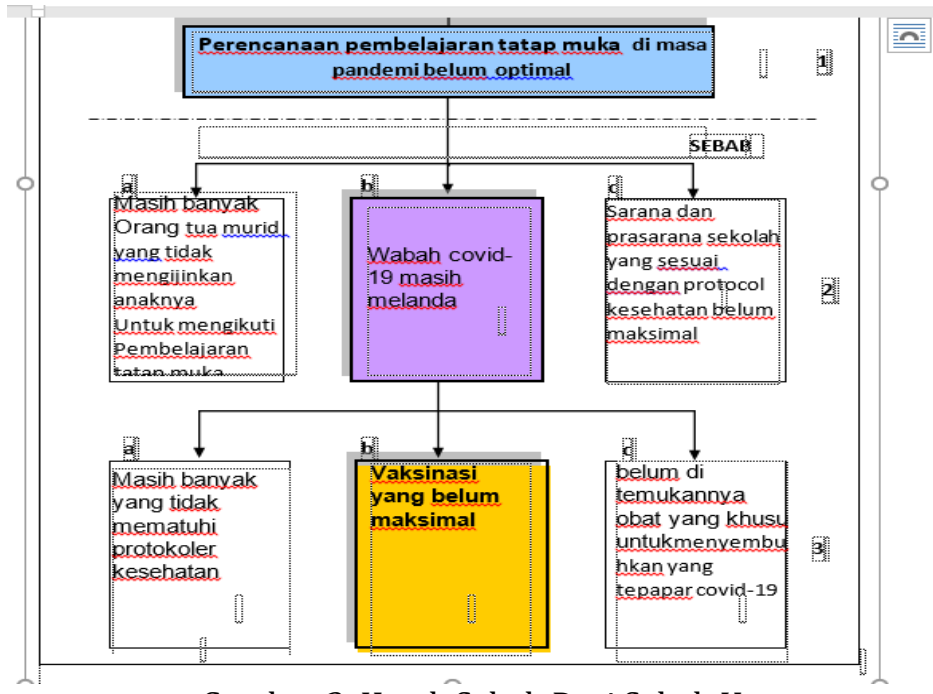

Gambar 3. Kotak Sebab Dari Sebab Utama

Langkah selanjutnya adalah mengidentifikasi apa akibat yang di timbulkan dari masalah utama.setelah mengetahui akibatnya.pindahkan lah akibat tersebut kedalam kotak akibat posisikan di atas kotak masalah.lihat pada gambar 4

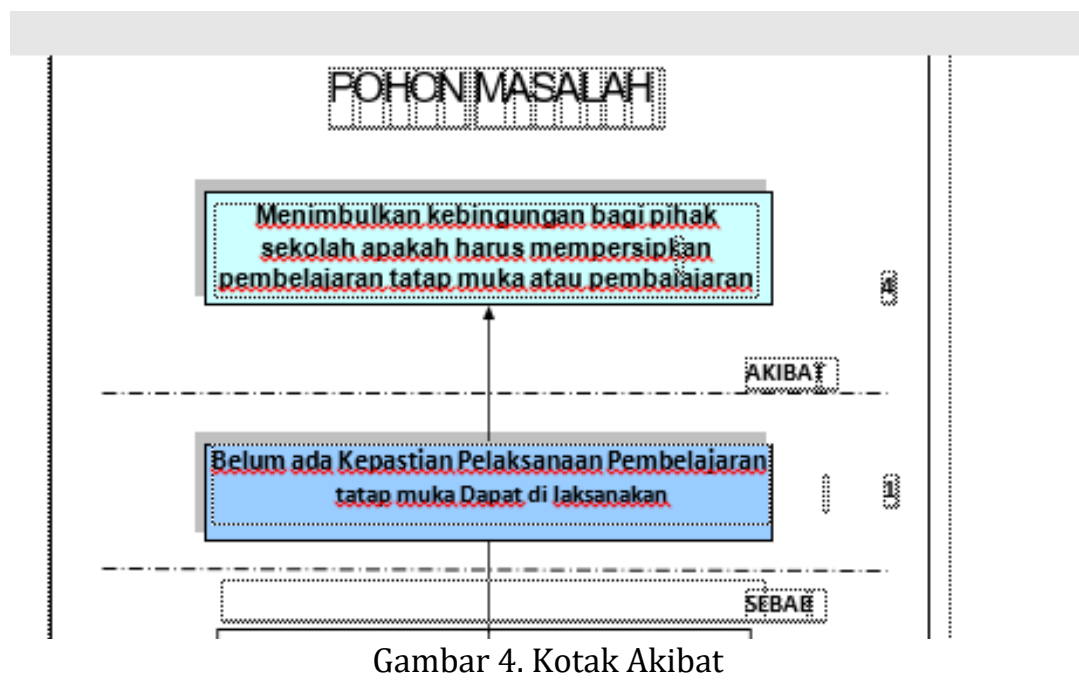


Setelah semua proses dilakukan maka pohon masalah telah jadi.Seperti pada Gambar 5

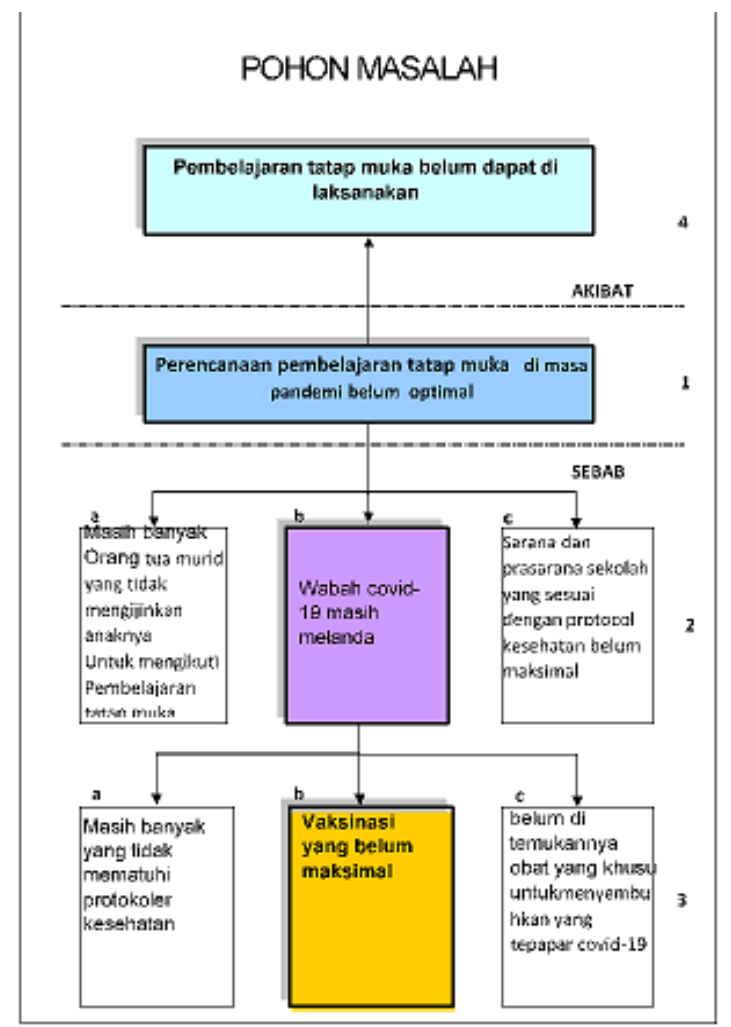

Gambar 5. Pohon Masalah

\section{Pohon Sasaran}

Pohon sasaran adalah kebalikan dari pohon masalah,jika di pohon masalah berisi kalimat negative maka di pohon sasaran berisi kalimat positif yang merupakan harapan-harapan dari solusi masalah. Caranya kalimat negative pada pohon masalah di rubah ke kalimat positf . Hasil dari konversi kalimat negative ke kalimat positf di pindahkan ke kotak pada pohon sasaran. Contoh pada kotak pokok masalah di pohon masalah adalah Perencanaan pelakasanaan pembelajaran tatap muka belum optimal, maka pada kotak sasaran utama pada pohon sasaran di ganti menjadi Perencanaan Pelaksanaan Pembelajaran Tatatp muka telah optimal.hal yang sama juga di lakukan pada kotak Akibat pada pohon masalah yang berisi pembelajaran tatap muka belum dapat di lakukan di rubah menjadi Pembelajaran tatap muka di masa pandemic dapat di lakukan.

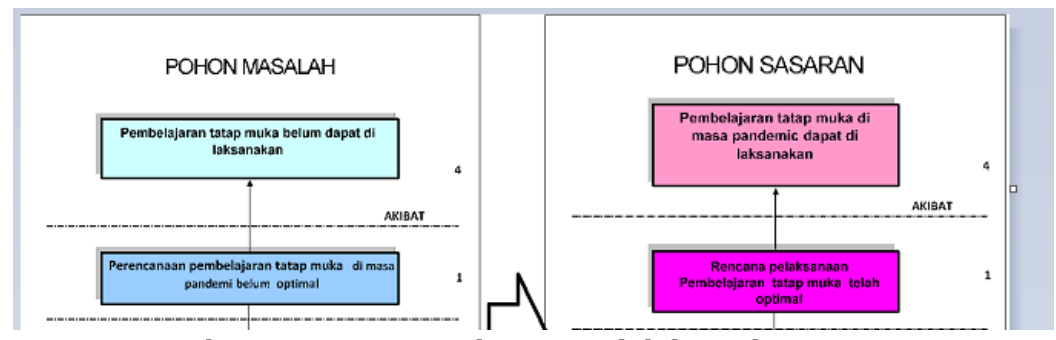

Gambar 6. Konversi pohon masalah ke pohon sasaran

Hal yang sama di lakukan pada semua kotak dipohon sasaran berisi kalimat positif hasil konversi dari pohon masalah 


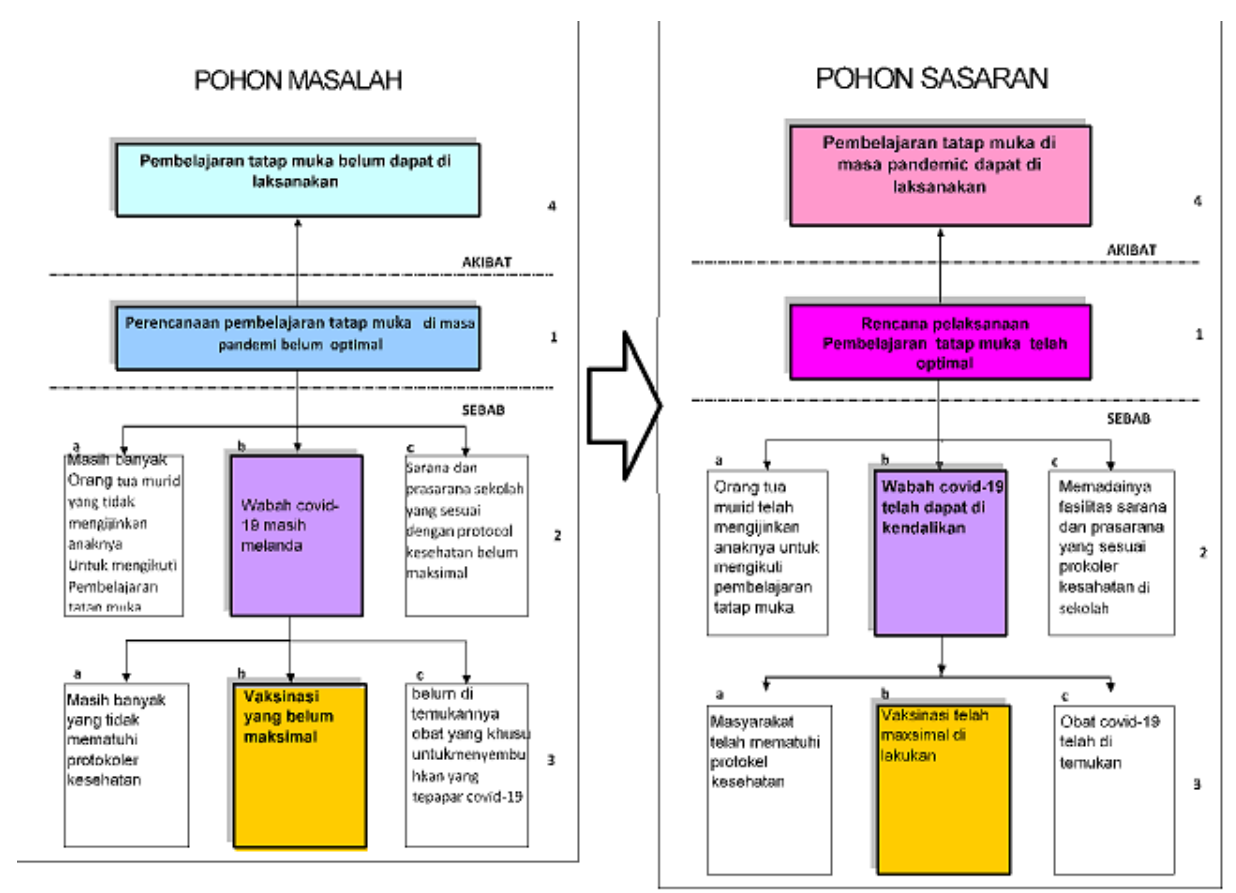

Gambar 6. Pohon Sasaran Hasil konversi dari pohon masalah

Pohon Alternatif

Pohon alternatif adalah teknik untuk mengidentifikasi atau mengembangkan alternatif pemecahan masalah atau arah tindakan yang dapat dipakai untuk mewujudkan sasaran tertentu. Untuk membuat pohon alternatif mulai dari bawah. posisikan kotak alternatif-alternatif yang bisa dilakukan di bagian paling bawah, kemudian menguji apakah harapan yang ada di pohon sasaran dapat di wujudkan dengan alternatif yang di tawarkan. Ada tiga solusi alternative yang dapat di lakukan oleh pihak sekolah agar pembelajaran tatap muka dapat di laksanakan yaitu, mempercepat vaksinasi terhadap pendidik dan tenaga kependidikan di sekolah, meningkatkan imun siswa,guru dan pegawai dengan cara memberi makanan bergizi atau berupa vitamin,sekolah mendorong pemerintah agar melakukan kerjasama dengan ilmuan untuk menemukaan obat covid-19.

Dari ketiga alternative solusi yang di tawarkan alternative pertama yang dapat di lakukan adalah mempercepat vaksinasi terhadap pendidik dan tenaga kependidikan di sekolah. Dengan maksimalnya vaksinasi yang dilakukan oleh sekolah, kita berharap penularan covid-19 dapat terkendali,jika penularancovid-19 dapat terkendali, maka perencanaan pelaksanaan pembelajaran tatap muka telah optimal.Sehingga harapan untuk pelaksanaan pembelajaran tatap muka pada juli 2012 mendatang benar-benar dapat terlaksana. Seperti yang di gambarkan pada diagram berikut

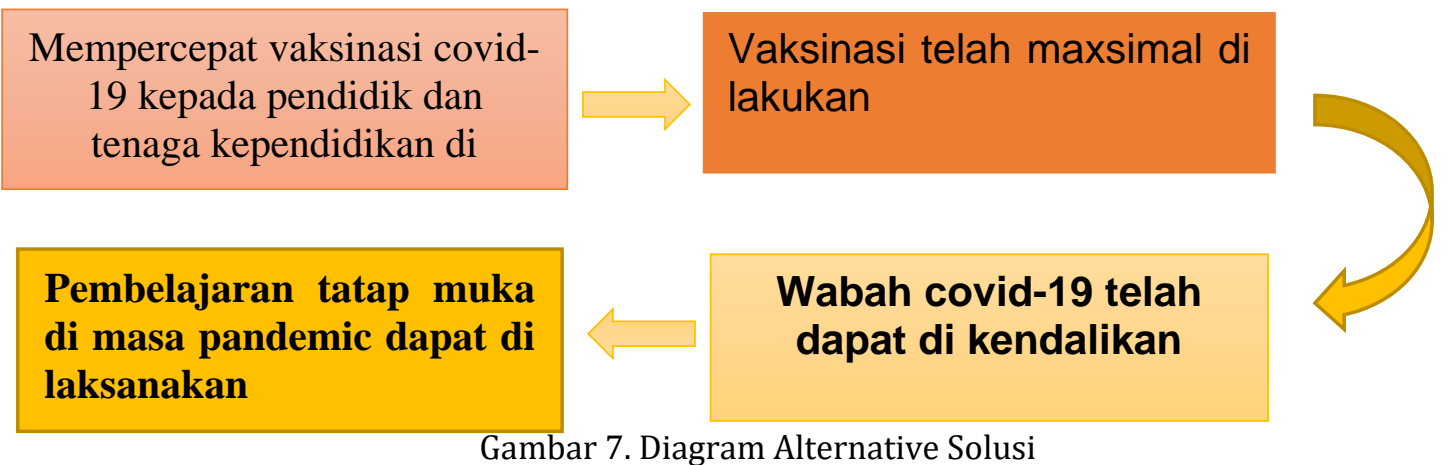

Gambar 7. Diagram Alternative Solusi 
Untuk lebih jelasnya di jabarkan dalam bentuk pohon alternatif

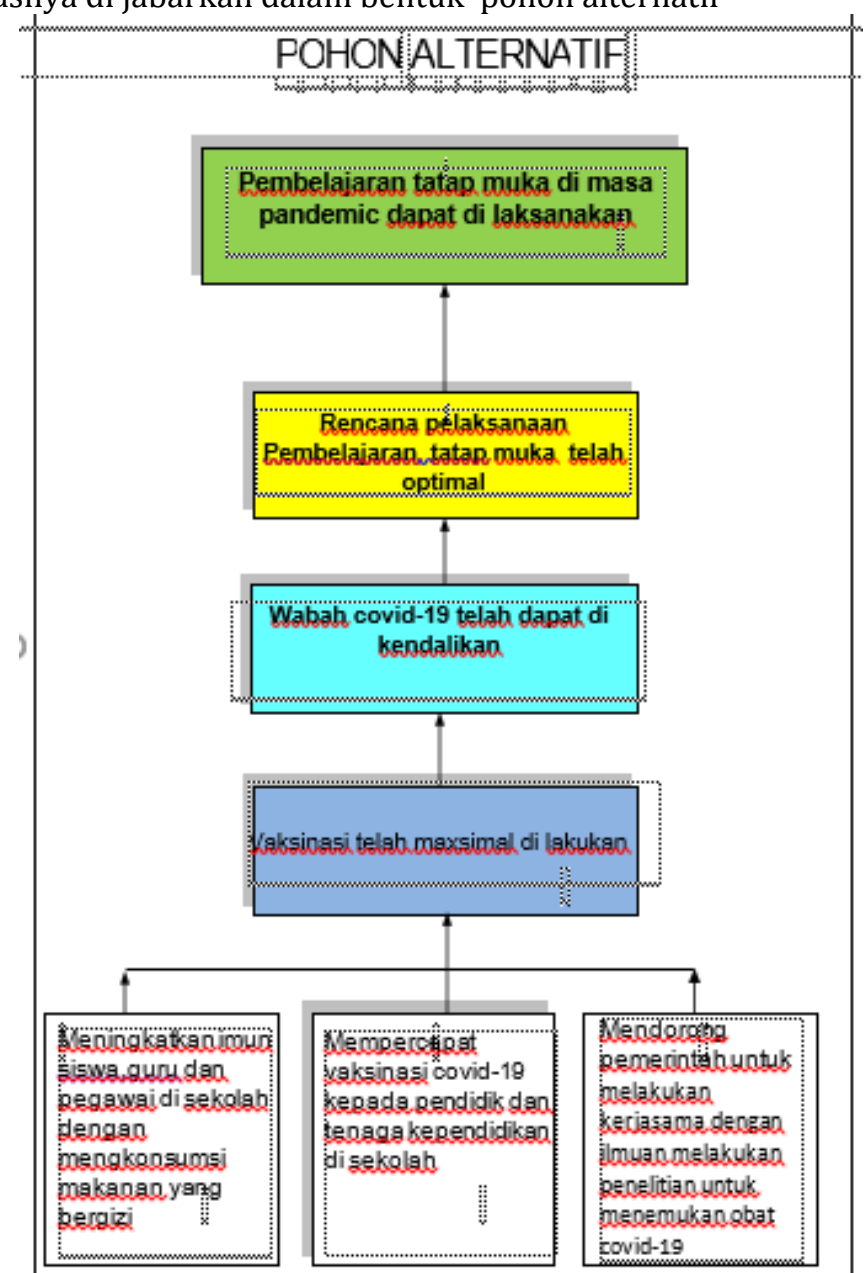

Gambar 8. Pohon Alternatif

\section{KESIMPULAN}

Agar kebijakan pemerintah tentang membuka kembali pemebalajaran tatap muka pada juli 2021 mendatang maka sekoloh sebagai eksekutor dari kebijakan tersebut harus melakukan tindakan yang konkrit agar kebijakan tersebut dapat terlaksana. Adupun tindakan yang dapat di lakukan oleh pihak sekolah harus mempercepat vaksinasi terhadap pendidik dan tenaga kependidikan di sekolah. Dengan maksimalnya vaksinasi yang dilakukan oleh sekolah, kita berharap penularan covid-19 dapat terkendali,jika penularancovid-19 dapat terkendali, maka perencanaan pelaksanaan pembelajaran tatap muka telah optimal.Sehingga dengan optimalnya perencanaan harapan untuk pelaksanaan pembelajaran tatap muka pada juli 2012 mendatang benar-benar dapat terlaksana.

Implikasi

Saat ini SMK Kristen Tagari telah melakukan vaksinasi kepada guru dan pegawai yang ada di SMK Kristen Tagari .Vaksinasi ini dibagi dalam tiga tahap.Pada vaksinasi tahap pertama untuk guru dan pegawai yang sudah di vaksin sekitar $20 \%$ yang di lakukan pada bulan April 2021, untuk tahap kedua guru dan pegawai yang telah di vaksin sekitar $30 \%$ yang dilaksanakan pada bulan Mei 2021 dan untuk tahap ketiga di rencanakan akan dilaksanakan pada bulan juni terhadap guru dan pegawai yang belum di vaksin. Dari kegiatan vaksinasi yang telah di lakukan di SMK Kristen Tagari seperti yang di uarikan di atas maka pembelajaran tatap muka pada Juli 2021 mendatang dapat terlaksana. 
Saran

Penulis menyarankan beberapa hal terkait penelitian ini antara lain: (1) Sekolah sebaiknya meningkatkan imun peserta didik,pendidik dan tenaga kependidikan dengan cara memberikan makanan bergizi agar dapat melawan covid-19. (2) Sekolah Melakukan vaksinasi kepada pendidik, tenaga kependidikan agar tidak rentan terhadap penularan covid-19. (3) Sekolah mendorong pemerintah agar bekerja sama dengan ilmuan untuk melakukan penelitian guna menemukan obat Covid-19. Penulis juga menyadari jika penelitian ini masih banyak kekurangan dan jauh dari kesempurnaan.sehingga perlu di lakukan penelitian lebih lanjut.

\section{DAFTAR PUSTAKA}

1. Ansori, A., \& Sari, A. F. (2020). Inovasi Pendidikan di Masa Pandemi Covid-19. Jurnal Literasi Pendidikan Nusantara, 1(2), 133-148.

2. Asmoko, H. (2012). Memahami analisis pohon masalah. Balai Diklat Kepemimpinan.

3. Budi, A. A. (2016). Manajemen Kinerja Berbasis Pohon Sasaran Kerja dan Inovasi Berlevel. Inovasi Pembangunan: Jurnal Kelitbangan, 4(02), 102-115

4. Herliandry, L. D., Nurhasanah, N., Suban, M. E., \& Kuswanto, H. (2020). Pembelajaran pada masa pandemi covid-19. JTP-Jurnal Teknologi Pendidikan, 22(1), 65-70.

5. Lestari, N. (2015). Keefektifan Pembelajaran Problem Based Learning Berbantuan Pohon Masalah dalam Meningkatkan Kemampuan Berpikir Kritis Siswa SMP (Doctoral dissertation, Universitas Negeri Semarang).

6. Rizky Amelia.(2019).Pengembangan Model Blavo (Blended Learning Audio Vidio) pada Perkuliahan Bahasa Indonesia di PGSD FKIP Universitas Lambung Mangkurat

7. Shaleh, M., \& Anhusadar, L. (2021). Kesiapan Lembaga PAUD dalam Pembelajaran Tatap Muka pada New Normal. Jurnal Obsesi: Jurnal Pendidikan Anak Usia Dini, 5(2), 2158-2167.

8. Khasanah, D. R. A. U., Pramudibyanto, H., \& Widuroyekti, B. (2020). Pendidikan dalam masa pandemi covid-19. Jurnal Sinestesia, 10(1), 41-48.

9. Yulianingsih, W., Suhanadji, S., Nugroho, R., \& Mustakim, M. (2020). Keterlibatan Orangtua dalam Pendampingan Belajar Anak selama Masa Pandemi Covid-19. Jurnal Obsesi: Jurnal Pendidikan Anak Usia Dini, 5(2), 1138-1150.

10. Ying, Y. (2007). Analisis Perbandingan Penerapan Pembelajaran Tata Bahasa China Antara Pembelajaran Tatap Muka Dengan Kombinasi Pembelajaran Jarak Jauh Dan Tatap Muka. Lingua Cultura, 1(1), 64-77. 